\title{
Effects of Feeding Forage Soybean Silage on Milk Production, Nutrient Digestion, and Ruminal Fermentation of Lactating Dairy Cows
}

\author{
E. Vargas-Bello-Pérez, ${ }^{*}$ A. F. Mustafa, ${ }^{* 1}$ and P. Seguin† \\ *Department of Animal Science, and \\ †Department of Plant Science, Macdonald Campus, McGill University, Sainte-Anne-de-Bellevue, Québec, Canada
}

\begin{abstract}
The objective of this study was to determine the feeding value of forage soybean silage (SS) for dairy cows relative to a fourth-cut alfalfa silage (AS). Forage soybean was harvested at full pod stage. Two iso-nitrogenous diets were formulated with a 48:52 forage:concentrate ratio. Soybean silage and AS constituted $72 \%$ of the forage in each diet, with corn silage constituting the remaining $28 \%$. Twenty Holsteins cows in early lactation were used in a switchback design. Four lactating Holsteins cows fitted with ruminal cannulas were used to determine the effects of dietary treatments on ruminal fermentation parameters and in vivo total tract nutrient utilization. Relative to AS, SS contained 15,28 , and $25 \%$ more neutral detergent fiber, acid detergent fiber, and crude protein, respectively. Dry matter intake ( 23.5 vs. $25.1 \mathrm{~kg} / \mathrm{d})$ and milk yield (35.5 vs. $37.2 \mathrm{~kg} / \mathrm{d}$ ) were lower for cows fed SS than for those fed AS. However, energy-corrected milk and milk efficiency were similar for both dietary treatments. Milk protein, lactose, and total solids concentrations were not influenced by dietary treatments (average 3.0, 4.7, and $12.6 \%$, respectively). However, cows fed SS produced milk with greater milk fat (3.8 vs. $3.6 \%$ ) and milk urea nitrogen concentrations ( $15.6 \mathrm{vs} .14 .3 \mathrm{mg} / \mathrm{dL}$ ) compared with cows fed AS. Ruminal $\mathrm{pH}$ was lower, whereas ruminal $\mathrm{NH}_{3}-\mathrm{N}$ concentration was greater in cows fed SS than in cows fed AS. Total tract digestibilities of dry matter, crude protein, and neutral detergent fiber were not influenced by silage type. We concluded that forage SS, when compared with AS, had a negative impact on feed intake and milk yield, whereas energycorrected milk, milk efficiency, and total tract nutrient digestion were similar.
\end{abstract}

Key words: milk yield, milk composition, soybean silage, nutrient utilization

Received June 27, 2007.

Accepted September 28, 2007.

${ }^{1}$ Corresponding author: arif.mustafa@mcgill.ca

\section{INTRODUCTION}

Soybeans were first introduced and utilized in North America as a forage crop. Until the early 1940s, more than half of the surface area planted to soybeans in the United States was harvested as forage, whereas fewer than half of the cultivars available were forage types (Hartwig, 1973). In eastern Canada and the northern United States, interest in soybeans as a source of forage has increased in recent years, in part because of the recurrence of alfalfa winterkill and the increase in corn acreage, with the resulting preference for shorter crop rotations (Seiter et al., 2004). Consequently, several new forage-type cultivars have been developed specifically for these regions (Devine, 1998; Sheaffer et al., 2001). Dry matter yields of forage cultivars range between 4.5 and 14 tons/ha in eastern Canada and the northern United States (Le Bulletin des agriculteurs, 2001; Darmosarkoro et al., 2001). Forage cultivars are usually taller and later maturing than typical oilseed cultivars (Darmosarkoro et al., 2001; Seiter et al., 2004).

In a previous study, we showed that forage-type soybean cultivars were well preserved as silages (Mustafa and Seguin, 2005). Our results also showed that chemical composition and ruminal nutrient degradabilities were significantly influenced by cultivar, with the Kodiak cultivar having lower fiber concentrations and greater ruminal degradabilities than the Mammoth cultivar. To our knowledge, no information is available regarding the feeding value of forage soybean silage (SS) for dairy cows. Our objectives were to determine the effects of feeding forage SS to lactating dairy cows on milk yield and composition, ruminal fermentation, and total tract nutrient digestibility.

\section{MATERIALS AND METHODS}

\section{Silage Preparation}

Forage soybeans (cultivar Kodiac) were seeded in the last week of May 2005 in Ste-Anne-de-Bellevue, Québec, Canada, on a Chicot fine sandy loam (seeding rate of $70 \mathrm{~kg} / \mathrm{ha}, 7,980$ seeds/ $/ \mathrm{kg}, 558,600$ seeds/ha). The soybean forage was harvested on August 15 at full-pod 
Table 1. Ingredients and chemical composition of dietary treatments (DM basis)

\begin{tabular}{lcc}
\hline & \multicolumn{2}{c}{ Dietary treatment } \\
\cline { 2 - 3 } Item & Soybean silage & Alfalfa silage \\
\hline Ingredient, \% & & \\
Soybean silage & 36.0 & 0.0 \\
Alfalfa silage & 0.0 & 36.0 \\
Corn silage & 12.0 & 12.0 \\
Crushed corn grain & 37.0 & 37.4 \\
Canola meal & 2.2 & 2.2 \\
Corn gluten meal & 1.7 & 1.7 \\
Corn distillers grains & 4.4 & 4.4 \\
Trituro & 4.3 & 4.4 \\
Sodium bicarbonate & 0.8 & 0.8 \\
Mineral mix ${ }^{2}$ & 1.1 & 1.1 \\
Urea & 0.5 & 0.0 \\
Chemical composition & & \\
DM, \% & 54.4 & 56.5 \\
Ash, \% & 6.3 & 6.6 \\
Ether extract, \% & 4.6 & 4.7 \\
NDF, \% & 36.7 & 34.1 \\
ADF, \% & 24.3 & 22.6 \\
Acid detergent lignin, \% & 5.4 & 4.9 \\
NSC, \% & 36.1 & 38.1 \\
CP, \% & 18.6 & 19.0 \\
Soluble protein, \% of CP & 50.0 & 51.7 \\
NPN, \% of CP & 48.8 & 48.6 \\
Neutral detergent insoluble protein, \% of CP & 12.4 & 12.9 \\
Acid detergent insoluble protein, \% of CP & 8.1 & 9.7 \\
NE ${ }^{3}{ }^{3}$ Mcal/kg & 1.59 & 1.64 \\
\hline & & \\
\hline
\end{tabular}

\footnotetext{
${ }^{1}$ Soya Excel (Beloeil, Québec, Canada). Contained (\%): 49 CP, 9.2 NDF, 6.4 ADF, 7 ether extract, 0.77 P, $0.2 \mathrm{Ca}, 0.32 \mathrm{Mg}, 2.1 \mathrm{~K}, 0.02 \mathrm{Na}$, and $0.04 \mathrm{Cl}$.

${ }^{2}$ Contained, per kg: $4.5 \% \mathrm{Ca}, 2.5 \% \mathrm{P}, 6.6 \% \mathrm{Na}, 1.5 \% \mathrm{Mg}, 1.2 \% \mathrm{~K}, 0.11 \% \mathrm{~S}, 1,372 \mathrm{mg}$ of $\mathrm{Fe}, 1,032 \mathrm{mg}$ of $\mathrm{Mn}, 1,500 \mathrm{mg}$ of $\mathrm{Zn}, 247 \mathrm{mg}$ of $\mathrm{Cu}, 16 \mathrm{mg}$ of I, $16 \mathrm{mg}$ of Co, $10 \mathrm{mg}$ of Se, 185,000 IU of vitamin A, 32,500 IU of vitamin $\mathrm{D}_{3}$, and 900 IU of vitamin $\mathrm{E}$.

${ }^{3}$ Calculated according to Weiss et al. (1992).
}

stage and when the lower leaves started to become yellow (R6; Fehr et al., 1971). A fourth-cut alfalfa forage was harvested at the early bloom stage. All forages were wilted to a targeted $30 \%$ of DM, chopped to a theoretical cut length of $10 \mathrm{~mm}$ with a forage harvester, and then ensiled in tower silos for $3 \mathrm{mo}$.

\section{Production Study}

Twenty Holstein cows of mixed parities (12 multiparous and 8 primiparous) in early to midlactation [BW $634 \pm 65 \mathrm{~kg} ; 69 \pm 38 \mathrm{DIM}$ (average $\pm \mathrm{SD}$ )] were blocked by parity and divided into 2 groups of 10 cows each. The cows were housed in tie stalls with free access to water. Two iso-nitrogenous diets were formulated with a 48:52 forage:concentrate ratio to meet the nutrient requirements of dairy cows in early lactation (NRC, 2001). The forage part of the diets consisted of $72 \%$ SS or $72 \%$ alfalfa silage (AS), with the remaining $28 \%$ consisting of corn silage in both diets (Table 1). Because of differences in CP content between AS and SS, urea was added to the SS diet to balance the dietary CP in the 2 diets. Diets were offered ad libitum as TMR twice daily at 0800 and $1600 \mathrm{~h}$.
Experimental periods $(n=3)$ consisted of $10 \mathrm{~d}$ of diet adaptation and $14 \mathrm{~d}$ of data collection in a switchback design. Feed intake and milk yield were measured on d 11 to 24 of each period. Cows were milked twice daily at 800 and $1600 \mathrm{~h}$, and daily milk samples were pooled by proportion according to milk yield at each milking. Diets were sampled daily during each collection period and composited by period. The composited feed samples were oven-dried at $60^{\circ} \mathrm{C}$ for $48 \mathrm{~h}$, ground through a 1$\mathrm{mm}$ screen by using a Wiley mill (Arthur H. Thomas, Philadelphia, PA), and stored at room temperature for later analysis. Orts were measured daily to determine daily intake for each cow.

\section{Ruminal Fermentation Parameters and Total Tract Nutrient Utilization}

Four multiparous lactating Holstein cows (average BW $710 \pm 81 \mathrm{~kg}$, DIM $148 \pm 69$ ) fitted with ruminal cannulas were used in a switchback design with 3 periods $(n=3)$ consisting of $14 \mathrm{~d}$ of diet adaptation and 7 $\mathrm{d}$ of data collection. Cows were housed in tie stalls and had continuous access to water. Dietary treatments were the same as in the production study. 
Chromic oxide was used as an inert external marker to determine total fecal output. Gelatin capsules containing $8 \mathrm{~g}$ of $\mathrm{Cr}_{2} \mathrm{O}_{3}$ were inserted into the rumen of each cow twice daily in equal intervals starting on $d$ 12 of each period. Grabbed fecal samples were collected 4 times daily during the last $3 \mathrm{~d}$ of each period at 0800 , 1200,1600 , and $2000 \mathrm{~h}$. Samples were then dried at $60^{\circ} \mathrm{C}$ in a forced-air oven for $48 \mathrm{~h}$ and pooled by cow within each period. Feed samples were collected during the fecal collection period and were dried as previously described and pooled by treatment within each period.

Samples of ruminal fluid were collected from various parts of the rumen with a syringe screwed to a stainlesssteel tube ending with a fine metal mesh (RT Rumen Fluid Collection Tube, Bar Diamond Inc., Parma, ID) on $d 19$ of each period prior to the morning feeding $(0$ $\mathrm{h}$ ) and at $2,4,6,8,10$, and $12 \mathrm{~h}$ postfeeding. Ruminal $\mathrm{pH}$ was determined immediately by using an Accumet pH meter (AB15 Plus, Fisher Scientific, Pittsburgh, PA). Following $\mathrm{pH}$ determination, $10 \mathrm{~mL}$ of ruminal fluid was preserved by adding $1 \mathrm{~mL}$ of $25 \%$ metaphosphoric acid for VFA determination, and $10 \mathrm{~mL}$ of ruminal fluid was preserved by adding $1 \mathrm{~mL}$ of $0.1 \mathrm{~N} \mathrm{HCl}$ to determine $\mathrm{NH}_{3}-\mathrm{N}$. Samples were immediately frozen $\left(-20^{\circ} \mathrm{C}\right)$ for later analysis.

\section{Chemical Analyses}

Ground feed and silage samples were analyzed for DM, ash, and ether extract by using standard procedures (AOAC, 1990). Neutral detergent fiber (Van Soest et al., 1991) and ADF (AOAC, 1990) were determined by using an Ankom Fiber Analyzer (Ankom Technology Corporation, Macedon, NY). Analysis of NDF was conducted without the inclusion of sodium sulfite and with the use of heat-stable $\alpha$-amylase. Acid detergent lignin (ADL) was determined according to AOAC (1990). Crude protein $(\mathrm{N} \times 6.25)$ was measured by using a Leco Nitrogen Analyzer (FP-428 Nitrogen Determinator, Leco Corporation, St. Joseph, MI). Soluble protein and NPN were determined according to Licitra et al. (1996), whereas acid (ADICP) and neutral detergent insoluble protein were determined by analyzing $\mathrm{NDF}$ and $\mathrm{ADF}$ residues for total N. Gross energy of feed samples was determined by using an oxygen bomb calorimeter (Parr Instrument Company, Moline, IL). Ground fecal samples were analyzed for DM, ash, CP, NDF, and gross energy as previously described. Chromic oxide in fecal samples was determined according to the procedure of Fenton and Fenton (1979).

Milk samples were analyzed for fat, protein, lactose, and MUN by using an infrared analyzer (MilkoScan, model Foss 4000, Foss Food Technology, Hillerød, Denmark). Milk TS were determined according to AOAC (1990).

Samples of ruminal fluid preserved for VFA analysis were centrifuged for $15 \mathrm{~min}$ at $11,000 \times g$ and analyzed for acetic, propionic, and butyric acids by using a gas chromatograph (Hewlett-Packard, Palo Alto, CA) equipped with a 15-m Nukol fused-silica capillary column (Supelco Inc., Bellefonte, PA). Isocaproic acid was used as an internal standard. Column temperature was fixed at $150^{\circ} \mathrm{C}$ for a run time of $8 \mathrm{~min}$. Injector and detector temperatures were 180 and $200^{\circ} \mathrm{C}$, respectively. Gas flows were 30,300 , and $30 \mathrm{~mL} \mathrm{~min}^{-1}$ for $\mathrm{He}$, air, and $\mathrm{H}_{2}$, respectively. Ruminal $\mathrm{NH}_{3}-\mathrm{N}$ was determined by colorimetry with a multichannel Lachat Autoanalyzer (Lachat Instruments, Milwaukee, WI).

\section{In Situ Ruminal Nutrient Degradabilities}

Equal portions (200 g) of the dried silages from the 3 periods were composited to obtain a single sample for SS and AS. Duplicate samples weighing $5 \mathrm{~g}$ were placed into nylon bags $(9 \times 21 \mathrm{~cm}, 41 \mu \mathrm{m}$ pore size, Ankom Technology Corporation). The nylon bags were then incubated in the rumen of 2 lactating Holstein cows (2 bags per treatment per time period per cow) fitted with flexible rumen cannulas for $0,3,6,12,24,48,72$, and $96 \mathrm{~h}$. The cows were fed ad libitum a 50:50 forage:concentrate total mixed diet that contained (DM basis) $6.9 \%$ ash, $17.8 \% \mathrm{CP}, 14.8 \% \mathrm{ADF}$, and $28.6 \% \mathrm{NDF}$.

At the end of the incubations, bags were removed from each cow and washed under cold tap water until the rinsing water was clear. Zero-hour disappearance was estimated by washing duplicate bags containing samples. Washed bags were dried at $60^{\circ} \mathrm{C}$ for a constant weight. Residues from the nylon bags were analyzed for DM, CP, and NDF as previously described. Ruminal nutrient disappearance was calculated from concentrations of these nutrients in the original samples and the nylon bag residues. Ruminal nutrient disappearance data were then used to determine nutrient kinetic parameters by using the equation of Dhanoa (1988):

$$
p=a+b\left(1-e^{-c(t-L t)}\right)
$$

where $\mathrm{p}$ is ruminal nutrient disappearance at time $t$, $a$ is the soluble fraction (\%), $b$ is the potentially degradable fraction (\%), $\mathrm{c}$ is the rate of degradation of the $\mathrm{b}$ fraction $(\% / \mathrm{h})$ and Lt is the lag phase (h). The parameters were estimated by PROC NLIN of SAS (SAS Institute, 1989) using iterative least squares regression (Gauss-Newton method). Effective degradabilities (ED) 
of DM, CP, and NDF were then calculated according to the equation of Ørskov and McDonald (1979):

$$
\mathrm{ED}=\mathrm{a}+\mathrm{bc} /(\mathrm{c}+\mathrm{k})
$$

where $\mathrm{k}$ is the ruminal outflow rate $(5 \% / \mathrm{h})$ and $\mathrm{a}, \mathrm{b}$, and $\mathrm{c}$ are as described above.

\section{Statistical Analysis}

Data on the production study and total tract nutrient utilization were analyzed as a switchback design using PROC MIXED of SAS (SAS Institute, 1989) with the following model:

$$
\mathrm{Y}_{\mathrm{ijkl}}=\mu+\mathrm{T}_{\mathrm{ij}}+\mathrm{P}_{\mathrm{ij}} \mathrm{C}_{\mathrm{k}}+\pi_{\mathrm{k}}+\tau_{\mathrm{h}}+\mathrm{e}_{\mathrm{ijk}}
$$

where $\mathrm{Y}_{\mathrm{ijkl}}$ is the observation; $\mu$ is the population mean; $T_{i j}$ is the effect of the jth cow in the ith sequence group, being a random effect, normally and independently distributed with a mean of zero and common variance of $\sigma_{\text {cow }}^{2} ; \mathrm{P}_{\mathrm{ij}}$ is the linear time trend of the jth cow in the ith sequence group; $\mathrm{C}_{\mathrm{k}}$ are the units of time $(\mathrm{X}=1$ in the first period, 0 in second period, and -1 in the third period); $\pi_{\mathrm{k}}$ is the effect of the kth period ( $\left.\sum_{\mathrm{k}}^{\pi \mathrm{k}}=0\right) ; \tau_{\mathrm{h}}$ is the true effect of the hth treatment $\left(\sum_{\mathrm{k}}^{\mathrm{th}}=0 ; \mathrm{h}=1,2\right.$, being a function of $i$ and $\mathrm{k}$ ); and $\mathrm{e}_{\mathrm{ijk}}$ is the random error, normally and independently distributed with a zero mean and a common variance of $\sigma_{\mathrm{e}}^{2}$.

Data on VFA, ruminal $\mathrm{pH}$, and $\mathrm{NH}_{3}-\mathrm{N}$ were analyzed as repeated measurements across time by using PROC MIXED of SAS (SAS Institute, 1989) with the following model:

$$
\mathrm{Y}_{\mathrm{ijkl}}=\mu+\mathrm{T}_{\mathrm{i}}+\mathrm{P}_{\mathrm{j}}+\mathrm{C}_{\mathrm{k}}+\mathrm{S}_{\mathrm{l}}+\mathrm{T}_{\mathrm{i}} \times \mathrm{S}_{\mathrm{l}}+\mathrm{e}_{\mathrm{ijkl}}
$$

where $Y_{i j k l}$ is the observation, $\mu$ is the population mean, $T_{i}$ is the treatment ( $i=1$ or 2 ), $P_{j}$ is the period $(j=1$, 2 , or 3$), \mathrm{C}_{\mathrm{k}}$ is the random effect of cow $[\mathrm{k}=1,2,3$, or $\left.4 ; \mathrm{C}_{\mathrm{k}} \sim \mathrm{N}\left(0, \sigma_{\text {cow }}^{2}\right)\right], \mathrm{S}_{\mathrm{l}}$ is the sampling time $(\mathrm{l}=0,2,4$, $6,8,10$, or $12 \mathrm{~h}), \mathrm{T}_{\mathrm{i}} \times \mathrm{S}_{1}$ is the treatment $\times$ time interaction, and $\mathrm{e}_{\mathrm{ijkl}}$ is the residual error $\left[\mathrm{e}_{\mathrm{ijkl}} \sim \mathrm{N}\left(0, \sigma_{\text {cow }}^{2}\right)\right]$. Data from the in situ trial were analyzed as a randomized complete block design using cows as blocks. Significance was declared at $P<0.05$.

\section{RESULTS AND DISCUSSION}

\section{Chemical Composition and In Situ Ruminal Degradabilities of SS}

Chemical composition of SS and AS is shown in Table 2. Relative to AS, SS contained $11 \%$ more NDF, $40 \%$ more ADL, and $25 \%$ less CP. Values of NDF and ADF for SS were in good agreement with those previously reported for the same cultivar (Mustafa and Seguin, 2005). However, CP content in the present study was $15 \%$ less than the value reported by Mustafa and Seguin (2005). In situ soluble DM and NDF fractions were greater $(P<0.05)$ for AS than SS, whereas the in situ soluble CP fraction was similar for both silages (Table 3). Slowly degradable DM, CP, and NDF fractions were not affected by silage type and averaged 38.6, 30.8, and $44.5 \%$, respectively. Relative to AS, SS had slower ( $P$ $<0.05$ ) rates of degradation of DM, CP, and NDF fractions. Effective ruminal degradability of DM, CP, and NDF were all greater $(P<0.05)$ for AS than SS (Table 3$)$.

Differences in ruminal nutrient degradabilities between SS and AS were mainly due to differences in ruminal nutrient degradation rates, particularly that of NDF (Table 3). The slower rate of degradation of the potentially degradable NDF fraction of SS relative to AS can be attributed to its greater ADL concentration (Table 2). Lignin has been proposed as a main factor in reducing forage fiber digestibility (Jung and Allen, 1995; Jung et al., 1997). Several studies have reported an increase in ruminal degradation rates of NDF when the concentration of ADL is reduced (Aydin et al., 1999; Oliver et al., 2004). The greater rate of degradation of the slowly degradable CP fraction of AS relative to that of SS is likely due to its lower ADICP concentration. A strong negative correlation between rate of degradation of the slowly degradable CP fraction and concentration of ADICP has been reported for forages (Hoffman et al., 1999). Ruminal degradability values of SS and AS were in good agreement with our pervious values (Mustafa et al., 2000; Mustafa and Seguin, 2003).

\section{Intakes, and Milk Yield and Composition}

Cows fed SS consumed less $(P<0.05)$ DM, CP, and NDF than cows fed AS (Table 4). Milk yield and SCM were greater $(P<0.05)$ for cows fed AS than for those fed SS. However, ECM, 4\% FCM, and milk efficiency were similar for both dietary treatments. Dietary NDF content and digestibility are major factors affecting the DMI and milk yield of dairy cows, particularly in early lactation, when DMI is often limited by rumen fill (Oba and Allen, 1999; Allen, 2000). The reduction in DMI, and consequently milk yield, for cows fed the SS diet can be attributed, at least in part, to the greater $(7.6 \%$ more) NDF content of the SS diet relative to that of the AS diet (Table 1). Neutral detergent fiber has been used as a chemical predictor of DMI (Waldo, 1986). Dry matter intake for diets with more than $25 \% \mathrm{NDF}$ decreases as the level of dietary NDF increases (Allen, 2000). For high-producing cows in early lactation, DMI 
Table 2. Chemical composition (mean \pm SD) of soybean and alfalfa silages (DM basis)

\begin{tabular}{lrr}
\hline & \multicolumn{2}{c}{ Silage } \\
\cline { 2 - 3 } Item & Soybean & Alfalfa \\
\hline $\mathrm{DM}, \%$ & $40.9 \pm 5.2$ & $44.5 \pm 1.7$ \\
$\mathrm{pH}$ & $5.29 \pm 0.57$ & $4.89 \pm 0.09$ \\
Ash, \% & $12.6 \pm 1.6$ & $10.0 \pm 0.7$ \\
Ether extract, \% & $1.5 \pm 0.4$ & $2.6 \pm 0.2$ \\
$\mathrm{NDF}, \%$ & $46.9 \pm 1.0$ & $42.5 \pm 0.4$ \\
ADF, \% & $37.7 \pm 1.4$ & $32.4 \pm 0.7$ \\
Acid detergent lignin, \% & $11.0 \pm 0.7$ & $7.6 \pm 0.5$ \\
CP, \% & $18.4 \pm 2.6$ & $24.4 \pm 0.6$ \\
Soluble protein, \% of CP & $58.2 \pm 3.6$ & $64.0 \pm 2.8$ \\
NPN, \% of CP & $56.7 \pm 2.7$ & $61.2 \pm 4.9$ \\
Neutral detergent insoluble protein, \% of CP & $28.5 \pm 2.7$ & $18.6 \pm 1.8$ \\
Acid detergent insoluble protein, \% of CP & $12.3 \pm 3.6$ & $8.8 \pm 1.6$ \\
NE ${ }_{\mathrm{L}}{ }^{1}$ Mcal/kg & $1.20 \pm 0.02$ & $1.44 \pm 0.06$ \\
\hline
\end{tabular}

${ }^{1}$ Calculated according to Weiss et al. (1992).

may be limited by gut fill when diets containing more than $32 \% \mathrm{NDF}$ are fed (Mertens, 1994). In the present study, both diets contained more than $34 \%$ NDF.

Neutral detergent fiber of SS was less degradable than that of AS (Table 2), which could also have contributed to the reduced DMI of cows fed the SS diet relative to those fed the AS diet. The effect of dietary NDF digestibility on the DMI of dairy cows is well documented, and several authors have reported a positive relationship between DMI and NDF digestibility (Oba and Allen, 1999; Oba and Allen, 2000). Oba and Allen (1999) indicated that a one-unit increase in NDF digestibility was associated with a $0.17-\mathrm{kg}$ increase in DMI and a $0.25-\mathrm{kg}$ increase in milk yield. Despite the negative effect of SS on DMI and milk yield, milk efficiency was similar for both dietary treatments, suggesting efficient utilization of nutrients from SS by dairy cows.

Table 3. In situ ruminal nutrient degradabilities of soybean silage relative to alfalfa silage

\begin{tabular}{lccccc}
\hline & \multicolumn{3}{c}{ Silage } & & \\
\cline { 2 - 3 } & Soybean & Alfalfa & & SEM & $P$-value \\
\hline Item & & & & \\
DM & 33.8 & 40.0 & 0.46 & $<0.001$ \\
Soluble fraction, \% & 39.5 & 37.7 & 1.14 & 0.16 \\
Slowly degradable fraction, \% & 6.0 & 8.0 & 0.80 & $<0.02$ \\
Degradation rate, \%/h & 0.62 & 0.54 & 0.43 & 0.69 \\
Lag time, h & 53.3 & 63.9 & 0.73 & $<0.001$ \\
Effective degradability, \% & & & & \\
CP & 60.1 & 59.6 & 2.15 & 0.18 \\
Soluble fraction, \% & 30.4 & 31.2 & 2.10 & 0.73 \\
Slowly degradable fraction, \% & 6.5 & 9.4 & 0.83 & 0.034 \\
Degradation rate, \%/h & 0 & 0 & - & - \\
Lag time, h & 76.9 & 79.9 & 0.59 & 0.004 \\
Effective degradability, \% & & & & \\
NDF & 10.0 & 15.3 & 0.67 & $<0.001$ \\
$\quad$ Soluble fraction, \% & 43.9 & 45.1 & 2.27 & 0.63 \\
Slowly degradable fraction, \% & 4.8 & 6.1 & 0.50 & 0.04 \\
Degradation rate, \%/h & 1.0 & 0.8 & 0.43 & 0.85 \\
Lag time, h & 31.2 & 40.6 & 0.75 & $<0.001$ \\
Effective degradability, \% & & & &
\end{tabular}

Milk fat and MUN concentrations were greater $(P<$ 0.05 ) in the milk of cows fed SS than in the milk of cows fed AS (Table 4). However, milk protein and lactose concentrations were unaffected by silage type. Apparent milk fat depression might result from increased milk fluid yield relative to milk fat yield (i.e., dilution effect), which explains the lack of difference in ECM between dietary treatments (Table 4). Increased milk volume is generally associated with reduced milk fat concentration (Murphy et al., 2000; Oba and Allen, 2000).

Table 4. Effects of feeding soybean silage on the performance of dairy cows

\begin{tabular}{|c|c|c|c|c|}
\hline \multirow[b]{2}{*}{ Item } & \multicolumn{2}{|c|}{ Dietary treatment } & \multirow[b]{2}{*}{ SEM } & \multirow[b]{2}{*}{$P$-value } \\
\hline & $\begin{array}{l}\text { Soybean } \\
\text { silage }\end{array}$ & $\begin{array}{l}\text { Alfalfa } \\
\text { silage }\end{array}$ & & \\
\hline \multicolumn{5}{|l|}{ Intake, $\mathrm{kg} / \mathrm{d}$} \\
\hline DM & 23.5 & 25.1 & 0.67 & 0.033 \\
\hline $\mathrm{CP}$ & 4.0 & 4.9 & 0.15 & 0.001 \\
\hline $\mathrm{NDF}$ & 7.4 & 9.3 & 0.25 & $<0.001$ \\
\hline \multicolumn{5}{|c|}{ Milk composition, \% } \\
\hline Fat & 3.78 & 3.58 & 0.051 & 0.017 \\
\hline $\mathrm{CP}$ & 3.17 & 3.18 & 0.022 & 0.76 \\
\hline Lactose & 4.69 & 4.69 & 0.012 & 0.89 \\
\hline TS & 12.65 & 12.61 & 0.079 & 0.73 \\
\hline MUN, mg/dL & 15.67 & 14.03 & 0.164 & 0.017 \\
\hline \multicolumn{5}{|l|}{ Yield, kg/d } \\
\hline Milk & 35.5 & 37.2 & 0.47 & 0.002 \\
\hline $\mathrm{ECM}^{1}$ & 32.1 & 32.9 & 0.33 & 0.33 \\
\hline $4 \% \mathrm{FCM}^{1}$ & 34.3 & 34.8 & 1.14 & 0.31 \\
\hline $\mathrm{SCM}^{1}$ & 33.5 & 34.4 & 1.09 & 0.035 \\
\hline Fat & 1.35 & 1.33 & 0.019 & 0.39 \\
\hline $\mathrm{CP}$ & 1.09 & 1.16 & 0.006 & $<0.001$ \\
\hline Lactose & 1.67 & 1.74 & 0.012 & $<0.001$ \\
\hline $\mathrm{TS}$ & 4.49 & 4.71 & 0.079 & 0.004 \\
\hline Milk efficiency ${ }^{2}$ & 1.56 & 1.52 & 0.012 & 0.34 \\
\hline
\end{tabular}

${ }^{1}$ Calculated according to Tyrrell and Reid (1965).

${ }^{2}$ Milk yield:DMI. 
Table 5. Effects of feeding soybean silage on ruminal fermentation parameters of ruminally cannulated cows

\begin{tabular}{lcccc}
\hline & \multicolumn{2}{c}{ Dietary treatment } & & \\
\cline { 2 - 4 } & $\begin{array}{c}\text { Soybean } \\
\text { silage }\end{array}$ & $\begin{array}{c}\text { Alfalfa } \\
\text { silage }\end{array}$ & SEM & $P$-value \\
\hline Item & 6.44 & 6.34 & 0.03 & 0.011 \\
$\mathrm{pH}$ & 23.8 & 18.5 & 1.36 & $<0.001$ \\
$\mathrm{NH}_{3}-\mathrm{N}, \mathrm{mg} / \mathrm{dL}$ & 78.6 & 81.6 & 3.08 & 0.34 \\
$\mathrm{VFA}, \mathrm{m} M$ & & & & \\
Molar proportion & 66.2 & 63.9 & 2.41 & 0.34 \\
$\quad$ Acetate & 25.2 & 27.6 & 1.67 & 0.18 \\
Propionate & 15.1 & 16.0 & 0.78 & 0.25 \\
Butyrate & & & & \\
\hline
\end{tabular}

\section{Ruminal Fermentation and Total Nutrient Digestibilities}

No time $\times$ silage interactions were observed for ruminal fermentation parameters; therefore, only main effects are reported (Table 5). Total and molar proportions of VFA were not influenced by dietary treatments. Ruminal $\mathrm{pH}$ and $\mathrm{NH}_{3}-\mathrm{N}$ were lower $(P<0.05)$ in cows fed AS than in cows fed SS. However, differences in $\mathrm{pH}$ were small and are not expected to be biologically significant. It is possible that the method used for collecting ruminal fluid (i.e., collection tube) might have resulted in overestimation of ruminal $\mathrm{pH}$. Differences in $\mathrm{NH}_{3}-\mathrm{N}$ concentration between dietary treatments are likely due to the addition of urea to the SS diet (Table 1). Concentration of ruminal $\mathrm{NH}_{3}-\mathrm{N}$ is usually increased when diets of lactating cows are supplemented with urea (Cameron et al., 1991). Furthermore, the SS diet contained 5\% less NSC than the AS diet. Hristov et al. (2005) showed that provision of rapidly fermentable carbohydrate reduced ruminal $\mathrm{NH}_{3}-\mathrm{N}$ concentration by decreasing $\mathrm{NH}_{3}-\mathrm{N}$ production or through enhanced uptake for microbial synthesis. The greater ruminal $\mathrm{NH}_{3}-$ $\mathrm{N}$ concentration for cows fed SS relative to those fed AS helps to explain the greater MUN content in their milk.

Total tract digestibility of DM, OM, CP, NDF, and gross energy were similar for the 2 dietary treatments and averaged 72.1, 72.9, 70.1, 55.7, and 71.0\%, respectively (Table 6). The lack of differences in total tract nutrient digestibilities between the SS and AS diets can be attributed, at least in part, to differences in DMI. High DMI, especially for diets containing more digestible fiber, are usually associated with decreased total tract nutrient digestibilities caused by a reduced ruminal retention time and therefore an increased passage rate. Oba and Allen (1999) indicated that forages with high in situ or in vitro digestibilities might have a shorter retention time, allowing greater DMI at the expense of total tract NDF digestibility. It is also possible that cows fed the SS diets had greater postruminal fermentation than cows fed the AS diet to compensate for reduced ruminal fiber degradability.
Table 6. Effects of soybean silage on total tract nutrient utilization by ruminally cannulated cows

\begin{tabular}{lcccc}
\hline & \multicolumn{2}{c}{ Dietary treatment } & & \\
\cline { 2 - 4 } Item & $\begin{array}{c}\text { Soybean } \\
\text { silage }\end{array}$ & $\begin{array}{c}\text { Alfalfa } \\
\text { silage }\end{array}$ & SEM & $P$-value \\
\hline Intake, kg/d & 26.0 & 27.7 & 0.19 & 0.025 \\
Digestibility, \% & 71.1 & 70.9 & 8.9 & 0.88 \\
DM & 71.8 & 71.7 & 10.3 & 0.95 \\
OM & 70.6 & 69.5 & 18.1 & 0.74 \\
CP & 57.8 & 53.5 & 32.2 & 0.27 \\
NDF & 71.9 & 70.0 & 1.83 & 0.32 \\
Gross energy & 3.11 & 3.01 & 0.03 & 0.17 \\
Digestible energy, ${ }^{1}{ }^{1}$ Mcal/kg & & & &
\end{tabular}

${ }^{1}$ Calculated as gross energy digestibility $\times$ dietary gross energy.

\section{CONCLUSIONS}

Under the conditions of our study, feeding forage SS reduced the DMI and milk yield of dairy cows when compared with AS, likely because of an increased content of NDF and its reduced ruminal degradability. Despite the negative impact on ruminal fiber degradability, forage SS had no effect on ECM, milk efficiency, and total tract nutrient utilization. More research is needed to determine the optimal stage of development at harvest and the long-term effects of feeding forage SS to dairy cows.

\section{REFERENCES}

Allen, M. S. 2000. Effects of diet on short-term regulation of feed intake by lactating dairy cattle. J. Dairy Sci. 83:1598-1624.

AOAC. 1990. Official Methods of Analysis. 15th ed. Vol. 1. Assoc. Off. Anal. Chem., Arlington, VA.

Aydin, G., R. J. Grant, and J. O’Rear. 1999. Brown midrib sorghum in diets for lactating dairy cows. J. Dairy Sci. 82:2127-2135.

Le Bulletin des agriculteurs. 2001. Du soya d'ensilage: C'est possible! Bull. Agric. Mi-Mars 2001. http://www.lebulletin.com/article.jsp?content=20010315_archives_0103bq Accesssed July18, 2006.

Cameron, M. R., T. H. Klusmeyer, G. L. Lynch, J. H. Clark, and D. R. Nelson. 1991. Effects of urea and starch on rumen fermentation, nutrient passage to the duodenum, and performance of dairy cows. J. Dairy Sci. 74:1321-1336.

Darmosarkoro, W., M. M. Harbur, D. R. Buxton, K. J. Moore, T. E. Devine, and I. C. Anderson. 2001. Growth development, and yield of soybean lines developed for forage. Agron. J. 93:1028-1034.

Devine, T. E., E. O. Hatley, and D. E. Starner. 1998. Registration of "Derry" forage soybean. Crop Sci. 38:1719-1720.

Dhanoa, M. S. 1988. On the analysis of Dacron bag data for low digestibility feed. Grass Forage Sci. 43:441-444.

Dhiman, T. R., and L. D. Satter. 1997. Yield response of dairy cows fed different proportions of alfalfa silage and corn silage. J. Dairy Sci. 80:2069-2082.

Fehr, W. R., C. E. Caviness, D. T. Burmood, and J. S. Pennington. 1971. Stage of development descriptions for soybeans, Glycine $\max ($ L.) Merrill. Crop Sci. 11:929-931.

Fenton, T. W., and M. Fenton. 1979. Determination of chromic oxide in feed and feces. Can. J. Anim. Sci. 58:631-633.

Hartwig, E. E. 1973. Varietal development. Pages 187-210 in Soybeans: Improvement, Production, and Uses. B. E. Caldwell, ed. Am. Soc. Agron., Madison, WI.

Hoffman, P. C., N. M. Brehm, L. M. Bauman, J. B. Peters, and D. J. Undersander. 1999. Prediction of laboratory and in situ of 
protein fractions in legume and grass silages using near-infrared reflectance spectroscopy. J. Dairy Sci. 82:764-770.

Hristov, A. N., J. K. Ropp, K. L. Grandeen, S. Abedi, R. P. Etter, A. Melgar, and A. E. Foley. 2005. Effect of carbohydrate source on ammonia utilization in lactating dairy cows. J. Anim. Sci. 83:408-421.

Jung, H. G., and M. S. Allen. 1995. Characteristics of plant cell walls affecting intake and digestibility of forages by ruminants. J. Anim. Sci. 73:2774-2790.

Jung, H. G., D. R. Mertens, and A. J. Payne. 1997. Correlation of acid detergent lignin and Klason lignin with digestibility of forage dry matter and neutral detergent fiber. J. Dairy Sci. 80:16221628.

Licitra, G., T. M. Hernandez, and P. J. Van Soest. 1996. Standardization procedures for nitrogen fractionation of ruminant feeds. Anim. Feed Sci. Technol. 57:347-358.

Mertens, D. R. 1994. Regulation of forage intake. Pages 450-493 in Forage Quality, Evaluation and Utilization. C. G. Fahey Jr., M. Collins, D. R. Mertens, and L. E. Mosser, ed. Am. Soc. Agron., Crop Sci. Soc. Am., and Soil Sci. Soc. Am., Madison, WI.

Murphy, M., M. Akerlind, and K. Holtenius. 2000. Rumen fermentation in lactating cows selected for milk fat content fed two forage to concentrate ratios with hay or silage. J. Dairy Sci. 83:756-764.

Mustafa, A. F., D. A. Christensen, and J. J. McKinnon. 2000. Effects of pea, barley, and alfalfa silage on ruminal nutrient degradability and performance of dairy cows. J. Dairy Sci. 83:2859-2865.

Mustafa, A. F., and P. Seguin. 2003. Characteristics and in situ degradability of whole crop faba bean, pea, and soybean silages. Can. J. Anim. Sci. 83:793-799.

Mustafa, A., and P. Seguin. 2005. Effects of variety on chemical composition and ruminal nutrient degradability of forage soybean. J. Dairy Sci. 88(Suppl. 1):385. (Abstr.)

NRC. 2001. Nutrient requirements of dairy cattle. 7th rev. ed. Natl. Acad. Sci., Washington, DC.
Oba, M., and M. S. Allen. 1999. Evaluation of the importance of the digestibility of neutral detergent fiber from forage: Effects on dry matter intake and milk yield of dairy cows. J. Dairy Sci. 82:589-596

Oba, M., and M. S. Allen. 2000. Effects of brown midrib 3 mutation in corn silage on productivity of dairy cows fed two concentrations of dietary neutral detergent fiber: 1 . Feeding behavior and nutrient utilization. J. Dairy Sci. 83:1333-1341.

Oliver, A. L., R. J. Grant, J. F. Pedersen, and J. O’Rear. 2004. Comparison of brown midrib- 6 and -18 forage sorghum with conventional sorghum and corn silage in diets of lactating dairy cows. J. Dairy Sci. 87:637-644.

Ørskov, E. R., and I. McDonald. 1979. The estimation of protein degradability in the rumen from incubation measurements weighed according to rate of passage. J. Agric. Sci. (Camb.) 92:499-503.

SAS Institute. 1989. SAS User's Guide: Statistics. SAS Inst. Inc., Cary, NC

Seiter, S., C. E. Altemose, and M. H. Davis. 2004. Forage soybean yield and quality responses to plant density and row distance. Agron. J. 96:966-970.

Sheaffer, C. C., J. H. Orf, T. E. Devine, and J. G. Jewett. 2001. Yield and quality of forage soybean. Agron. J. 93:99-106.

Tyrrell, H. F., and J. T. Reid. 1965. Prediction of the energy value of cow's milk. J. Dairy Sci. 48:1215-1223.

Van Soest, P. J., P. J. Robertson, and B. A. Lewis. 1991. Methods for dietary fiber, neutral detergent fiber, and nonstarch polysaccharides in relation to animal nutrition. J. Dairy Sci. 74:3583-3597.

Waldo, D. R. 1986. Effect of forage quality on intake and forageconcentrate interactions. J. Dairy Sci. 69:617-631.

Weiss, W. P., H. R. Conrad, and N. R. St. Pierre. 1992. A theoretically based model for predicting total digestible nutrient values of forages and concentrates. Anim. Feed Sci. Technol. 39:95-110. 